\title{
SCREEN MEMORY: THE JEWISH QUESTION
}

\author{
KRISTIAN FEIGELSON* \\ Sorbonne Nouvelle University Paris \\ kristian.feigelson@univ-paris3.fr \\ CATHERINE PORTUGES* \\ University of Massachusetts, Amherst \\ portuges@complit.umass.edu
}

\begin{abstract}
This paper explores intersections of memory and cinematic representation in contemporary Hungarian film culture. Since the fall of the Berlin Wall in 1989, with the concomitant financial crisis in Hungarian cinema, a number of films have foregrounded questions of Jewish identity, a taboo subject on Hungarian screens after 1945 when nationalistic historiography supported an official government culture of denial with regard to responsibility for the deportation and extermination of some 550000 Hungarian Jews. The production of relatively few narrative and documentary films on this subject, the essay suggests, is perhaps in part attributable to the fact that the Hungarian uprising of 1956 tended to eclipse the drama of Jewish deportation and genocide. The authors consider post-socialist filmmakers' uses of the past in the context of the country's current nationalistic climate, interrogating the impact of controversal films such as László Nemes’s Son of Saul (2015, Grand Prix, Cannes Film Festival ; Academy Award for best foreign film) within a Hungarian society still conflicted about its Holocaust trauma.
\end{abstract}

Keywords: Hungary, cinema, History, Jewish question, genocide, memory, remembrance.

Since the fall of the Berlin Wall in 1989, and after a long period of crisis in the Hungarian cinema's finances, a number of films have dealt with the question of Jewish identity, a rather taboo subject on Hungarian screens after 1945. How then - in Hungarian public space - can we consider the role of films that have become the focus of intergenerational debates about the Holocaust? What approaches to the past has Hungarian cinema initiated since WWII in revisiting this trauma?

\section{The Cinema: Place of Memory?}

Through this theme, cinema has once again become a place of memory, a crossroads of Hungarian history. At the beginning of the post-war period, concentra- 
tion camps had not yet become an object of historical inquiry, nor of a public striving to forget this history. Few testimonials or narratives appeared at a time when the traces of war were being erased in the interest of rebuilding society as quickly as possible ${ }^{1}$. In spite of international pressure to learn the truth, the case of Swedish diplomat Raoul Wallenberg, who died in the Soviet Union in 1945 after saving some hundred-thousand Hungarian Jews, crystallized post-war paradoxes in Hungary and abroad. Such treatment of the Holocaust is more specific to the filmic work of a second or third generation of postwar filmmakers, who focus on the place of Jewish identity in Central Europe, ${ }^{2}$ posing questions of truth and probability. Is it possible to evoke the concept of intergenerational transmission when the filmmakers' imagination is confronted with a history built on traumatic gaps $^{3}$ ? Without going back to the origins of Theodor Herzl, born in Budapest in the Austro-Hungarian Empire before beginning his own reflection on the Zionist project in Vienna, filmmakers today are rediscovering a very different Jewish history - that of the Holocaust - divided between family memory and the absence of official writings on the subject ${ }^{4}$. As in other European societies, it took Hungary some twenty five years - nearly a generation - to gradually address these Jewish questions on the screen.

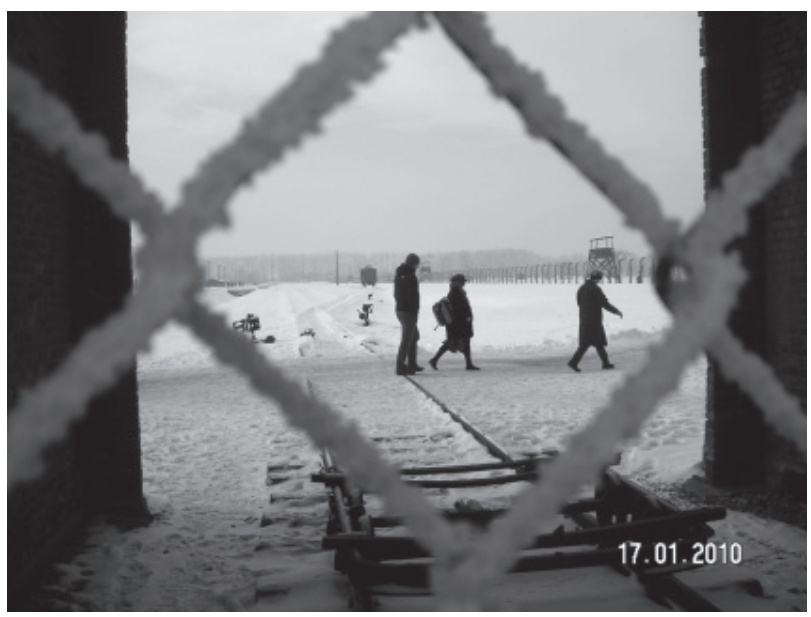

Birkenau (2010) photo Kristian Feigelson

The construction of the nation state in Central Europe at the beginning of the nineteenth century no doubt made it possible to take the measure not only of the idea of nation, but also of the gradual appearance of new nationalist discourses around "Magyar" identity and its anti-semitic corollary5. Does one remain Jewish after becoming Hungarian? Jewish communities in Hungary were well integrated 
at the end of the nineteenth century, and $60 \%$ of families assimilated through mixed marriages. This community, which enjoyed an unprecedented level of development after its political emancipation in December 1867, was also the first to suffer discriminatory legislation after WW I and the collapse of the AustroHungarian Empire. While the first anti-Jewish laws of the 1920s were not widely applied, they were well implemented in the 1930s and 1940s. In 1938, Jews were directly targeted as a subversive community by a fascist government openly collaborating with Nazi Germany. From Hungary’s entry into the war in 1941 to the German invasion in March 1944, the Jewish community in the Budapest ghetto of nearly 70,000 people was preserved, unlike the exterminated Jewish communities in Poland, before mass deportations were undertaken following the HitlerHorthy pact of March 18, $1944^{6}$.

The Christian churches also allowed a number of converted Jews to escape deportation despite a climate of indifference and international pressure at the time. Since the fall of the Berlin Wall, Hungarian society has, we argue, fallen short of the task of proposing a clear history of its responsibility in the Shoah, as Hungary proved unable to defend its citizens who were left to witness the mass disappearance.

\section{From Disappearance to Emptiness}

Hungarian narrative cinema has accorded relatively little space to these questions.

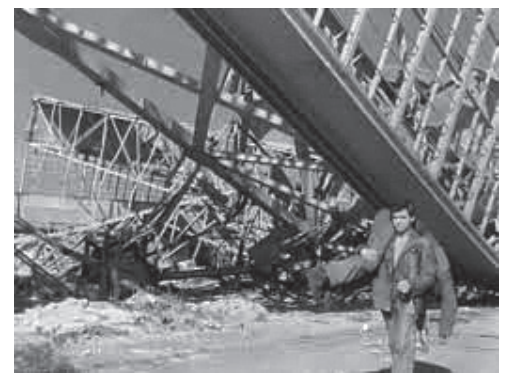

Géza von Radvány’s Somewhere in Europe (1947)

In 1947, Géza von Radványi’s pioneering film Somewhere in Europe was the first to portray the disasters of war, evoking abandoned children wandering the countryside, including Jews not openly identified as such, and the first to suggest the responsibility of the Arrow Cross Party in the disaster. Released in the middle of the Stalin era, Félix Máriássy’s 1953 film, Spring Comes to Budapest is an allusive and somewhat anecdotal reading of Ferenc Karinthy's short story about 
a young man who joined the resistance movement and fell in love with a young Jewish woman. Until the late 1960s, nonetheless, the Jewish question remained a minor one in order to circumvent Communist-era censorship, which tended to privilege allegorical representations. Subsequently, the director Miklós Jancsó, for whom "Hungarians always feel trapped in an immense space," examined the extent of what was not said7. In Silence and Cry (1968), for example, and Agnus Dei (1970), the director probed the origins of Hungarian fascism and counterrevolution after 1919, filming immense, windswept plains in an aestheticization of a vacant landscape that proposes the Jewish question as a metaphor for disappearance.

The Jewish question had already appeared in István Szabó's films during the Communist period as an autobiographical narrative, eventually returning to that of repressed personal Jewish identity that had been so difficult to express at the time.

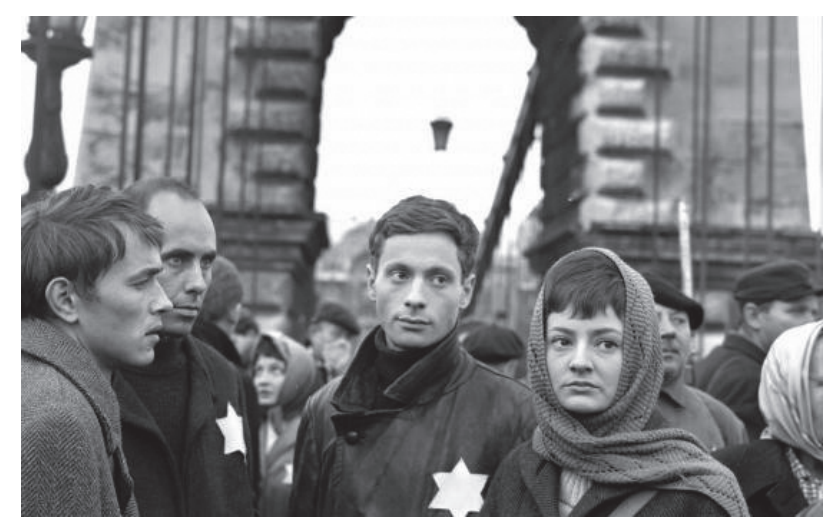

Apa (1966) István Szabó

His 1966 film Father highlighted the power of Jewish subjectivity, although the portrayal of the Hungarian Uprising of 1956 eclipsed the drama of deportation in 1944. Not unlike in the Soviet Union, a thaw became a necessary precursor to the process of bearing witness to trauma and Hungarian culture's Jewish heritage. The arrests and deportations in Father were recreated in the center of Budapest in 1966 with the dogged perseverance of a filmmaker born in 1938 to a Jewish family, although later criticized for being an informant under the Communist regime's secret police ${ }^{8}$. In order to play the role of a Hungarian Nazi, the hero, Takó, sews a yellow star on his jacket before going to meet his companion, Anni, who recalls her family's disappearance in Auschwitz. Their serious dialogue raises questions of dual Jewish and Hungarian identity. Similarly, in Cold Days (1966), András Kovács returns to the same period through the lens of the 
Serbian massacres of 1942 and the criminal proceedings that followed, sealing the shared fates of Jews and Hungarians. Despite the East/West Cold War context, these two films are undoubtedly inscribed in the aftermath of the Eichmann trial in Jerusalem in 1961. How can the responsibility of ordinary citizens, a general passivity in the face of deportations, or the notion of collective crime or responsibility be explained in a communist State where ideology has replaced the rule of law? Perhaps it can be said that, in a certain sense, through the prism of WW II, when the Soviets served as new liberators, the repressed Jewish question gradually re-emerged on the public stage. In Impostor (1965), Zoltán Fábri foregrounds the the origins of the Hungarian fascism and its visceral anti-Semitism. Likewise, in Silence and Cry (1968) Jancsó portrays the climate of oppression and domestic violence conducive to anti-Semitism. Hungarians could, however, also be depicted behaving righteously, as in Jancsó’s 1968 film The Confrontation, in which seminarians hide a young Jewish boy, or later in Fábri's Fifth Seal (1976), which addressed the rescue of young persecuted Jews. In any case, the debate on the Hungarian Jewish question seems to remain external to the society in question, primarilycommented by historians, ${ }^{9}$ while visual representation is almost absent. In von Radványi’s Circus Maximus (1980), the escape of fugitives becomes a common cross to bear. Much later, in Imre Gyöngyössy and Barna Kabay's The Revolt of Job (1983), at the end of the war, a Jewish child is faced with the arrest of his adoptive parents. In Pál Sándor's Deliver Us from Evil (1982), the allegory of a tragic and evil national history is all but religious.

\section{A Fragmented Imaginary}

The Jew within becomes a metonymic reprise both of suffering and of collective responsibility in the face of disappearance. The revival of the Jewish question was a minor part of Hungarian cinematic production after $1989^{10}$. How can this representation of trauma by omission be understood? How does it proceed from a fragmented imaginary? How can the unspoken parts of history be told in a post-totalitarian context now dominated by vindictive populism? By the time the debate had been re-opened, nearly a decade had passed since the fall of the Berlin Wall. István Szabó’s fictional fresco Sunshine (1999) was produced largely with foreign capital and outside Hungary; and, Judit Elek's 1995 film Awakening was a portrait of a young Jewish girl in the $1950 \mathrm{~s}^{11}$. Given that some 15 to 20 feature films have been produced each year and, since the end of the war, Hungary has produced more than 800 fiction films, relatively few have approached an issue so central to the history of Hungary ${ }^{12}$. Since 1945, worldwide, nearly 500 feature, documentary and television films have been devoted to this aspect of history or to the impact of the Holocaust ${ }^{13}$. 
In Hungary, it was not until the mid-1960s that these questions were evoked. Many years later, Szabó's Sunshine depicted an epic fresco of lost collective Jewish identity, ${ }^{14}$ thematizing asimilation in its many contradictions and sufferings, associating archival images with fiction.

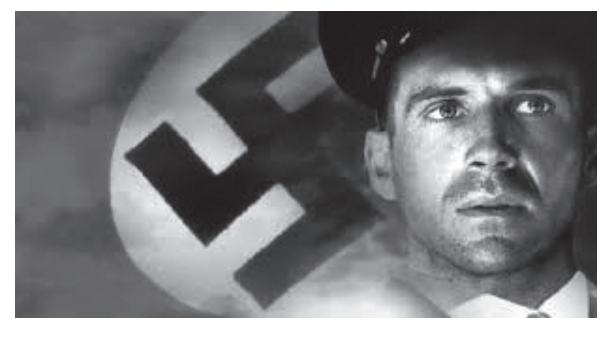

Sunshine,(1999) István Szabó

The family's original name, Sonnenschein, later changed to Sors (meaning 'fate'), serves as a reference for understanding a return to Jewish identity. The film relates the tale of four generations of a Jewish family, the Sonnenscheins, marked by the Austro-Hungarian Empire (1867-1918) during WW I, the Horthy regime (1920-1944) after the Treaty of Trianon and the collapse of the Empire in 1920, which partially explains the rise of a nationalist spirit of revenge, culminating in the Arrow Cross Party (1941-1945). Until then, despite having been better protected in comparison to other Jewish communities in Central Europe, the mass deportation of 550,000 Hungarian Jews to the extermination camps accelerated at the end of the war, under the impetus of the occupying Nazi forces. Sovietization (19451956) after the 1947 elections and Mátyás Rákosi’s rise to power, as well as the domination of the Hungarian Workers' Party repatriated from the Soviet Union, considered Jewish questions to be taboo until the arrival of Imre Nagy in 1953, executed in 1958 after the Hungarian Uprising. Henceforth, the symbolic date of 1956 excluded in-depth debate on the reality of the Jewish genocide of 1945 . The Jewish question was modified in the Soviet perspective, a liberating and dominating power in which Stalinism appeared as a doctrine imported and reappropriated by the victors. Already in My Way (1964), Jancsó had recalled these memories of war marked by social schizophrenia wherein the Soviet liberator assimilates the Russian occupying force in 1956. While it was ultimately only in the post-1989 period that any real debate was opened, in alternating phases, the Kádáar era made several timid ventures into the taboo territory of Hungarian collaboration in these massive deportations. In fact, Sunshine romanticised the integration of the Jewish elite in Hungary. The policy of integration led to a loss of Jewish identity whereby the Jewish community gradually dissolved into a collection of isolated individuals by late 1989 after reliving this generational history in search of its roots ${ }^{15}$. 


\section{Between Testimony and Representation}

If fictional treatments remained strangely silent or in the background, only addressing the deeply-rooted traumas of the Jewish genocide in Hungarian society in the mid-1960s, what may be said with regard to Hungarian documentary film? In 1985, Gyula Gazdag made Package Tour, an accunt of a group of Auschwitz survivors' pilgrimage in search of their history, which in its own way recalls Emmanuel Finkiel's films on the subject. Edith Köszégi and Sándor Simó’s Pictures for Our Children (1990) is a search for the Jewish children of the pre-war era found in a family album. Judit Elek, a Jewish filmmaker who experienced the Occupation first-hand, directed Memoirs of a River (1989) regarding the anti-semitic Tiszaeszlár case which divided Hungary in the $19^{\text {th }}$ century. A similar theme appears in herdocumentary To Speak the Unspeakable: the Message of Elie Wiesel (1996), in which the Nobel laureate retraces his footsteps from Transylvania to Auschwitz.. Could it be, then, that the Holocaust was more a literary preoccupation than a cinematic one, the latter being less capable of representing the unrepresentable and the unnameable? After 1989, heroes were confronted by the guilt of the survivors: in Glamour (2000), Frigyes Gödrös shows the fate of persecuted Jews, whereas in Andor Szilágyi’s Rose's Songs (2003), Jews take refuge in an opera singer's Budapest villa, sheltered only by their protector's song. In Ildikó Szabó's Chacho Rom (2002), the fate of the Jews and the persecution of the Roma takes the form of a folkloric performance. In the interstices between documentary film's challenges with regard to bearing witness and fictional representations, the question of what is representable then arises.

This debate had, however, already been addressedin Imre Kertész's Nobel prizewinning semi-autobiographical novel, Fateless, written in 1975 and adapted thirty years later by István Szabó’s former director of photography Lajos Koltai’s dreamlike triptych. The gradual development of the plot offers a dramatic progression of the narrative around a succession of scenes that illustrate the experience of the concentration camps. ${ }^{16}$

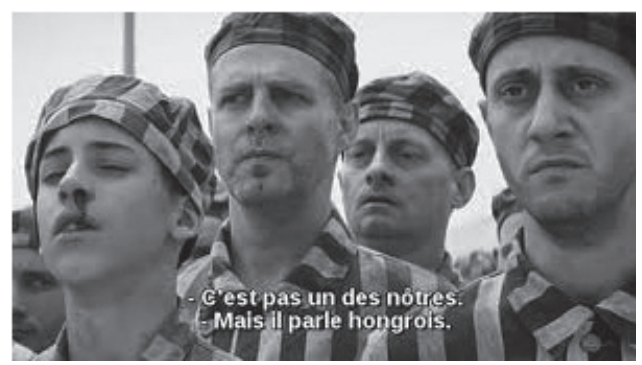

Fateless (2005) Lajos Koltai 
While it may have failed to bridge the gap between on-screen testimony and representation, the film succumbs to the lure of naturalism, highlighting the discrepancy between narrative testimony and visualplausibility ${ }^{17}$ thereby reconstituting the violence s of the Holocaust. The gap then becomes clear between lived experience and a posteriori testimony conveyed in a fictionalized space. How can film translate literary language or aesthetic research? Can it shed as much light on the cinematic apparatus as on the gravity of the problems brought to the screen? If Fateless claims to retrace the writer's own experience in Buchenwald in 1944, it is as much about the Holocaust in general terms as about the exceptional destiny of a human being.

Yet despite its marginalized impact, cinema partially succeeds in negotiating the zone between public and private space. At once marginalised and central, the return to the issue of Jewish identity despoiled or denied is the work of a generation of younger directors, struggling to find the traces of a taboo history. These films include amongst others, András Salamon's Lost Family, János Szász’s The Witman Boys (1997) and They Were My Neighbors (2006), Laszló Martinidesz’s From Mauthausen to Dob Street (2004), Zsuzsanna Gellér-Varga's Synagogue for Sale (2007), Barbara Spitzer's Memories of a Journey (2005), and Diana Groó’s Miracle in Krakow (2004). These films draw on a series of ambiguities, evoking the ghostly memory of a culture that is both present and vanished as in Georges Zsiga's Starry Budapest (2011) with interviews of survivors depicting the Jewish life in "Budapest étoilée ». Unlike in Germany, the disappearance of the Jews does not play a central role in a Hungarian national recovery of history.

In this reactivation of memory, Péter Forgács' untiring work in the reconstitution of amateur archival films goes the furthest. The Bartos Family (1988) and Free Fall (1996) from the Private Hungary series (1988-2002), recount the destiny of European Jewish families caught in the turmoil of the rise of Nazism.

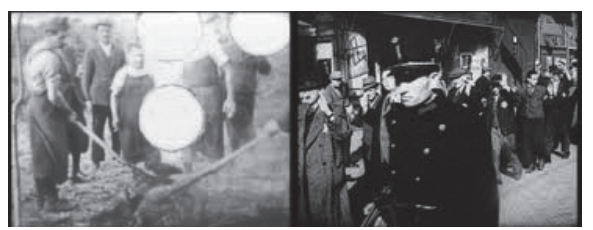

Maelstrom (1997) Péter Forgács

The Jewish question then becomes no longer necessarily a Hungarian one, instead denoting a universal referent. In family chronicles such as Maelstrom (1997) and Danube exodus (1998), the missing Dutch Jewish families and rescued Slovakian Jewish families are portrayed at the turn of the $1940 \mathrm{~s}^{18}$. 


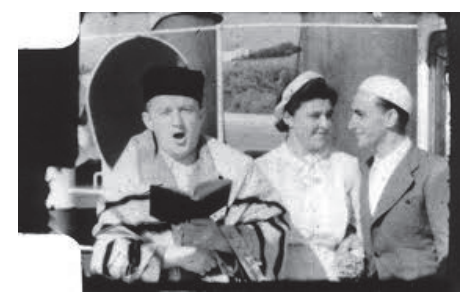

Danube exodus ( 1998) Péter Forgács

By placing themselves on the side of the victims, Forgács's films suggest the executioners' indifference. Using sound, silence and color film, Forgács’ juxtaposition of the fate of the executioners with that of the victims offers a profound meditation on the banality of evil.

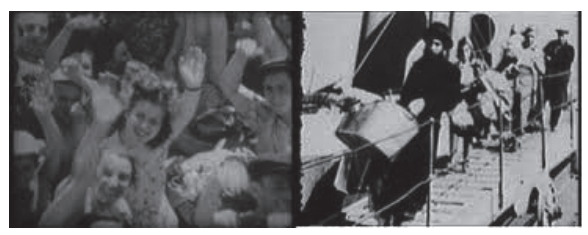

Danube exodus (1998) Péter Forgács

The montage puts these traces of the past back into perspective, foregrounding a history that had never really been accounted for. Péter Forgács' revisited archive makes it possible to reconstruct and reinterpret a history that is still evolving. As the past became eradicated, a threat against jewish identity , history became a main task for the filmmaker. The fragments of individual and anonymous history, reconstituted in this patient work on film archives, testifies - beyond documentary or fiction - to the force of the return of the repressed. The past of the

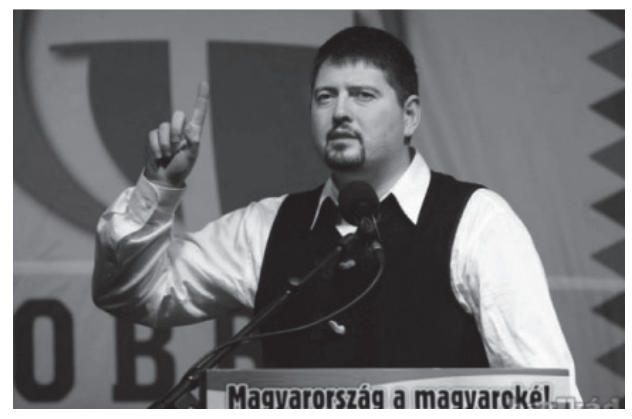

Csanád Szegedi in Keep quite (2016) Sam Blair 
concentration camps then extends beyond Hungary's borders, becoming a common European crisis of identity.Although the Holocaust was the common lot of European Jewry, each society experienced its own particular relationship to it. Lately, Keep quiet ( 2016) directed by Sam Blair, a UK-Hungarian coproduction, raised a new debate about Hungarian anti-Semitism .

The film described the different faces of the extremist neo-nazi Jobbik party, when Csanád Szegedi, its leading figure and European deputy, learned that he was himself a Jew as his grand-mother was also deported in Auschwitz. His whole world forever changed and gradually he became a practicing Jew. The films tracked the life transformation of this man.

\section{From Shoah to Son of Saul: An Intergenerational Dialogue}

As a counterpoint to the silence that marked productions from this period little known outside of Hungary, László Nemes’s Son of Saul (2015) brings the Nazi slaughterhouse to world screens. The film's long takes show the links between the Sonderkommandos and deported Auschwitz-Birkenau prisoners in the autumn of 1944. Filmed in Hungary in a most artisanal fashion, the film launched a debate about the concentration camps in Hungarian public space upon its release. A hybrid film based on historical events, and the only first fiction feature selected in the main competition category at the Cannes International Film Festival, Son of Saul was awarded the Festival's Grand Prix, the first time in thirty years that a Hungarian film has been thus acknowledged. It went on to win the Golden Globe for Best Foreign Language Film (2016) and the New York Film Critics Circle Award for Best First Film, the Independent Spirit Award, and the Oscar for best foreign film at the $88^{\text {th }}$ Academy Awards.

The film's treatment does not suppress the brutality of the concentrationary experience. To the contrary, this experience is amplified by a narrative that is supported by the soundtrack for the necessities of staging. The camera is completely immersed in the gas chambers. The generational drama is transposed in a fictional mode in this unlikely portrayal of a man, Saul, who amidst the horrors of Auschwitz, searches for a place to bury a child he thinks is his son in order to restore a semblance of humanity and meaning to life. In contrast to earlier Hungarian films, the representation of the concentration camps in Son of Saul is no longer elliptical or metaphorical; rather, it frames the industrial scale of extermination in an excessive style. The aestheticisation of the concentration camps disguises the narrative in an effort to depict the unimaginable and invisible aspects of everyday life in the univers concentrationnaire.

But, as we know from Hungarian and indeed global film history, cinema and the Holocaust has a long and complicated relationship. In the 72 years since 
the end of WW II, what had once been a prevailing discourse that insisted upon the absolute and unquestioning unrepresentability of the Holocaust has come under increasing scrutiny, as younger generations of filmmakers, writers and philosophers argue for the ethical necessity of reconstructing or imagining Holocaust representation. As we see from the proliferation of film festivals and film studies scholarship as well as journalistic, fictional and poetic texts, Holocaust representation has continued to flourish well into the $21^{\text {st }}$ century, gaining momentum even as its perspective shifts, as a third generation adds its voice to the chorus of post-Holocaust filmmakers. In negotiating these complex thematic imperatives and representational strategies, bold new works examine those tropes and tensions for a generation removed temporally and spatially from the extended trauma, under the aegis of evolving notions of post-memory, the intergenerational transmission of trauma, inherited memory, questions of Jewish cultural identity and assimilation, and imaginative reconstructions of the past. ${ }^{19}$

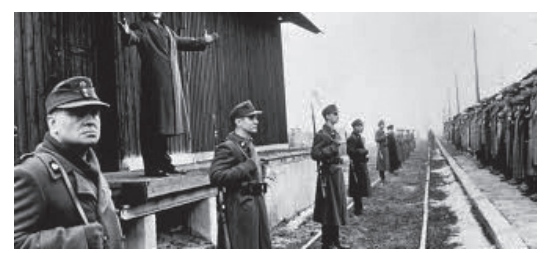

Son of Saul (2015) László Nemes

Claude Lanzmann's magisterial nine-and-a-half-hour long Shoah, originally released in 1985 and re-released in a 30 ${ }^{\text {th }}$ anniversary edition, at once embodies and advocates the primacy of testimony and witnessing so prevalent in the postwar era while proscribing the use of archival images in favor of eyewitness testimony, then the most urgent focus for survivors and historians of the period. As a counter-narrative to visualizations of the camps, the début fiction feature Son of Saul brings to the screen a controversial chapter of Holocaust history: the role of the Sonderkommando (the special command unit known as Geheimnisträger, bearers of secrets), teams of Jewish prisoners forced to assist the SS in the gas chambers and crematoria, themselves in turn condemned to extermination. The film is directed by the then 38-year-old Hungarian director, László Nemes, whose own family were Holocaust victims: " A part of my family was assassinated in Auschwitz. It was something we talked about every day. When I was little, I had the impression that "evil had been done". I imagined it like a black hole buried within us; something had broken, and my inability to grasp exactly what it was kept me isolated. » 


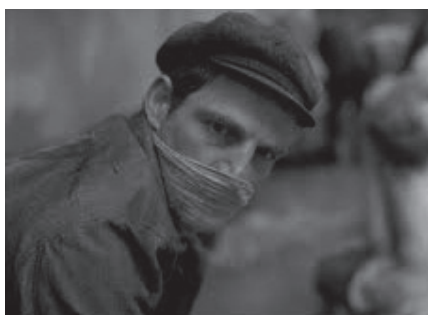

Son of Saul (2015) László Nemes

Nemes was inspired by his discovery of the publication of hidden manuscripts written by Sonderkommandos buried in the grounds of the crematoria in 1944: from 1945-1980, eight sets of documents by five known authors were recovered. Retrospectively known as the Scrolls of Auschwitz, they are of extraordinary immediacy, composed as they were within the camps, and include witness accounts, letters and lists in Yiddish, Greek, French and Polish that raise critical questions with regard to the ethics, memory and interpretation of Holocaust testimony.

Saul (played by Géza Röhrig ) is forced to lead prisoners into the fictitious showers of the gas chambers; in over-the-shoulder point-of-view throughout, extended shots of his impassive face against a blurred background, and an immersive wall of chaotic sound design, Nemes creates a claustrophobic hell of confusion and incomprehension. Indeed, in contrast to Primo Levi's view of the Sonderkommando as numbed servants of the Nazis, the writers of the Scrolls engaged in acts of resistance of which the writings themselves were a important part. Saul's moral dilemma-to participate in the extermination machine or join its victims-is a foregone conclusion. Because the Sonderkommando were summarily executed to remove evidence of Nazi atrocities, his own demise is simply a matter of time, as Nemes explains his own conception of the film's visual representation.

What connection can we find between Shoah and Son of Saul? Unlike in certain Holocaust films motivated by a redemptive narrative, there is no savior here, no heroic or rescuing figure, only victims trapped in the killing zone. " I didn't want to make a film with a distant, detached point of view, " says Nemes, instead seeking to "place the audience from the point-of-view of one person in the middle of the killing machine. Otherwise the Holocaust becomes an abstract concept and the audience can back away. " ${ }^{20}$

Nonetheless, as a descendant, so to speak, of Shoah, Son of Saul is perhaps after all not a film about the Holocaust, seeking neither to denounce nor describe its horrors; rather, it places the spectator in the Sonderkommando's cinematic body, evoking the sensation of seeing through his terrorized gaze, hearing strictly 
what he hears. Every shot is tightly framed and often in close-up, accompanied by a disorienting sound mix of SS voices in Hungarian, German, Polish, Russian and Yiddish, mixed with concentration-camp slang. The set, designed by Hungarian architect László Rajk, who was also responsible for designing the Hungarian exhibition at Auschwitz, is essential to the film's taut energy. Long takes, at times of as much as four minutes duration, executed with a hand-held camera, required sets of complete rooms that could accommodate 360-degree takes for which Rajk recreated a Nazi crematorium in an abandoned 1912 warehouse on the outskirts of Budapest.

It is at this point that Saul seems to realize that, in Röhrig's reading, " this boy belongs to him and he belongs to the boy. Even for a second the boy survived the gas chamber-he survives and then is killed by the Nazi doctor. " ${ }^{21}$ This death, then, is different from the others, offering Saul a moment of emotion, of empathy and identification. Whether or not it is his own son-a question left ambiguous in the film-through Saul's seemingly random dedication to the fate of this one individual, can the viewer, too, engage authentically with the otherwise overwhelming reality of the camp? Desensitized and psychologically annihilated by his inhuman tasks as a Sonderkommando, Saul is suddenly galvanized, consumed by the desire to recover the child's body for burial and to identify a rabbi to recite the mourners' Kaddish. The dénouement, criticized by some critics as a reductio ad absurdum, sees Saul swept up in the Sonderkommandos' attempted escape that takes him across a river, where the precious body he has 'saved' drifts away in the current, and ultimately taking refuge in a shed in the forest where his fellow fugitives plan their next moves. Suddenly, a small blond (Polish, we may imagine) boy appears, glimpses the men and quickly runs off. The ambiguous conclusion may be read as a moment of transcendence for Saul, whose face grows beatific at the sight of him, perhaps imagining in his madness that his 'son' is alive, or simply from the joy of seeing a living child.

Unlike Spielberg's Schindler's List, in refusing to depict the Holocaust as 'décor'-a trivialization for which Lanzmann has reproached Spielberg-Nemes proposes instead to limit himself to the raw reality of quotidian details while resisting the lure of voyeurism, instead de-coupling each frame from familiar or unquestioned representational modes. This is accomplished through Saul's gaze alone in images often blurred, out of focus or oblique, and through the deafening, often unbearable diegetic noise heard off-screen. Resisting the kind of redemptive discourse notoriously rejected by Lanzmann, Saul's obstinately determined struggle may be read as leaving open the possibility of a hopeful gesture even from the depths of despair.

Son of Saul thus reframes the camp without engaging in the kind of 'mirroring' or repetition of violence and atrocity that has been the object of so much critical debate Holocaust representation. Its boldly existential terms counter the 
more conventional narrative approach of a film such as Fateless a decade earlier (with its embrace of iconographic images of beauty despite horror) without betraying Lanzmann's ethical proscription of fictionalized portrayals of the univers concentrationnaire-indeed, of representation itself-as if cognizant of Adorno's proscription that « to write poetry after Auschwitz is barbaric. » In press conferences at the film's Cannes premiere and often thereafter, the lead actor, Géza Röhrig, urged greater understanding of-and renewed debate on-the controversial role of the Sonderkommando. Considering that cinema may always be regarded with suspicion with regard to the Holocaust, these debates continue to fuel controversy. As Lanzmann has noted, the autumn of 1944 was a particular moment in the chronology of Auschwitz when some 250 Jews assigned to the Sonderkommando unit organized a mutiny, succeeding in exploding crematorium No. IV and the adjacent gas chamber before being massacred by the Nazis. The revolt, a documented historical event, is suggested in Son of Saul as background to the fictional narrative of a man seeking to bury a child with dignity. To embody the daily life of an Auschwitz Sonderkommando, Nemes chose a hybrid representational mode, neither fully fiction nor documentary, inhabiting a " grey zone » in the interstices of the inferno: "Even in the darkest hours of mankind, there might be a voice within us that allows us to remain human. That's the hope of this film." Nemes believes Hungarians have not dealt with the trauma of the Holocaust, during which some 600,000 Hungarian Jews perished, almost all after Nazi Germany invaded in March 1944. "Every kid should watch it, » he said of the film, "not because the cinemas should be full, but that many of them lack empathy. " ${ }^{22}$

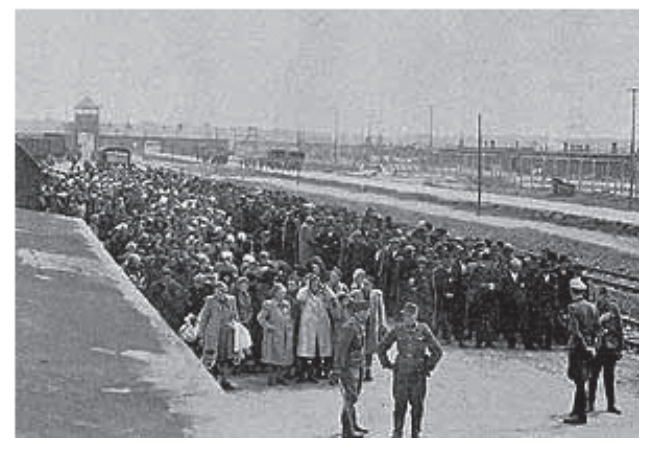

Hungarian Jews arriving to Auschwitz (1944)

Like Spielberg, who approached the Holocaust via the true story of a thousand Jews rescued by a single German industrialist, Nemes tells the singular story of a man determined to bury a boy he believes to be his son. How can cinema make history visible? And how can images help us reimagine history? As suggested 
above, the Holocaust has traditionally been understood as beyond the limits of representation, as unimaginable, an idea that can be traced from Adorno's caution regarding the impossibility of poetry after Auschwitz: "These four photographs deeply affected me. They attest to the extermination, they constitute evidence, and ask essential questions. What should be done with an image? What can it represent? What viewpoint should we have when faced with death and barbarity? ${ }^{23}$ The four photographs Nemes references became notorious in the aftermath of a photographic exhibition, “Mémoire des camps”, in Paris in 2001, remarkable in that they are the only existing photographs taken from inside the gas chambers documenting the process of mass extermination ${ }^{24}$. Taken in 1944 by a member of the Sonderkommando, the photographic images were smuggled out of the camps in a tube of toothpaste destined for the Polish resistance. DidiHuberman's catalogue essay accompanied the exhibition and marked a distinct turn in Holocaust discourse by interrogating previously sacralized boundaries of the unknowable and unthinkable. The first two blurred images were taken inside the gas chambers as Sonderkommando members carry out their grotesque tasks in outdoor funeral pyres: "But you, dear László Nemes, you have chosen not the radical black or the radical silence. Your film is terribly impure, sonorous and colored...you have therefore not forgotten the dark, but instead you have taken it out of its abstraction. $\gg{ }^{25}$ At the same time, Georges Didi-Huberman sustains an ongoing dialogue with Claude Lanzmann around questions of representability ${ }^{26}$. And by making the Sonderkommando and the gas chambers the subject of Son of Saul, Nemes may be seen to refute the idea of imaginaive retreat as an ethical response to the Holocaust: in contrast to Lanzmann's privileging of word and testimony over images, Nemes incontrovertibly positions the image at the heart of his project, thereby radically extending and significantly advancing the intergenerational dialogue.

\section{A Symptomatic Cinema?}

The fall of communism has led to manifold changes in the representation of the Holocaust, opening access to archival sources in Central and Eastern Europe that have altered the way younger generations of filmmakers are engaging with this history. It seems to be a sort of turning point for anew generation of young filmmakers. Still a minority in a Hungarian climate that has remained rather passive, if not outright hostile to such issues, often displaced in public debate by that of discrimination against the Roma. A number of directors used the microcosm of family to explore this topic, producing plausible narratives ranging from comedy to tragedy in the silence of the postwar period. The collective experience of the Holocaust in Hungary is no longer ignored but harbors a kind of bitter nostalgia. 
Over the course of history, these directors gradually freed themselves from postwar victimization, appearing as true historical subjects in their own right within the set of problems raised by those films' personal rewriting of history. How can an accurate filmic representation of such a complex collective history be achieved when one's work is determined by a concern for truth and reconciliation in a public debate still marked by anti-Semitism? This intermittent questioning of Jewish identity is endemic to Hungarian culture; today, it is either disparaged or misused by Victor Orbán and a majority supported by the extreme right. Thus it remains divided between an often inaudible collective debate and a still-traumatized individual memory. The smooth transition from Communism after 1990 was replaced by a new nationalist reconstruction. The Hungarian Nation today fuses a mythical and mystifying past, as the new Constitution of 2012 places itself under the aegis of Saint Stephen and the Christian doctrine of the Holy Crown formulated as early as 1222. In response to the enduring weight of the Holocaust in Hungary and its quasi-collective repressed discourse, and in the populist context of draconian laws, an identity-symptom, as it were, is being constructed in the cinema. The power of these images, in Freud's term"screen memory,"survives. More than seventy years after the Holocaust, the contribution of cinema as a "place of memory», reimagining and reexamining also images or events, is one might argue more and less to a kind of gesture towards self-recognition and ultimately responsibility in the complex process of coming to terms with the Holocaust in Hungary to-day.These cinematic representations have managed over the course of a generational history to finally legitimize a taboo topic in the near silence of contemporary society.

*Kristian Feigelson is a sociologist and professor of film studies at the Sorbonne Nouvelle University. The author of various articles on Hungarian cinema (Cinéma hongrois: le temps et l'histoire, Théorème 7, 2003), this paper was the subject of a debate at the Paris Memorial de la Shoah in April 2012 and the Hungarology Symposium in Pécs in August 2016.

*Catherine Portuges is Professor of Comparative Literature, Director of the Interdepartmental Program in Film Studies and Curator of the Massachusetts Multicultural Film Festival at the University of Massachusetts Amherst. She is the author of Screen Memories: The Hungarian Cinema of Márta Mészáros, Indiana University Press, 1993; Cinema in Transition in Central and Eastern Europe After 1989 (eds Catherine Portuges and Peter Hames), Temple University Press, 2013, and numerous articles and books chapters on Hungarian cinema.

\section{Notes}

1 The authors wish to thank Precious Brown for her work proofreading and translating. See Elie Wiesel's Night published in Paris in 1958 (Les Editions de Minuit) with a preface by François Mauriac. Elie Wiesel was born in 1928 in Sighet, Kingdom of Romania. He recounts the experience of death and dehumanization during his fam- 
ily's deportation in May 1944 to Auschwitz-Birkenau with thousands of Hungarian Jews: "Never shall I forget that night, the first night in the camp, which has made my life a long night, locked seven times. Never shall I forget that smoke...”

2 The notion of second generation referred to the children who had Jewish descendants who survived the Holocaust, who bore the scars of the trauma without having been directly confronted with it. See Suleiman, Susan, 2002. The 1.5 generation: thinking about child survivors and the Holocaust. American Imago, 59 (3), 277-295.

3 In this respect, see Catherine Portuges' article, 2007. Intergenerational transmission: the Holocaust in Central European cinema. In: Sabbadini, Andrea ed. Projected Shadows. New York: Routledge and London Institute of Psychoanalysis, 73-91.

4 See Imre Kertész's writings, particularly Kaddish for an Unborn Child, Actes Sud, Arles, 1995 published in 1990 in Budapest. Also see other Hungarian writings such as György Konrád's autobiographical novel, Departure and Return, Mille et une nuits, Paris, 2002, or Adam Biro's Ancestors of Ulysses, PUF, Paris, 2002.

5 See Patai, Rafael, 1996. The Jews of Hungary: Culture, Psychology. Detroit: Wayne State University Press.

6 See, amongst others, Deák, István, 2004. The Holocaust in Hungary. Hungarian Quarterly, 15 (176), 50-70.

7 Miklós Jancsó, Image et Son, No. 217, May 1968.

8 Regarding the Jewish question in the films of Szabó, see Hirsch, Joshua, 1999. István Szabó: Problems in the Narration of Holocaust Memory. Journal of Film and Video. Spring 51(1), 3-21. See also István Szabó’s interview with Jean-Pierre Jeancolas, 2006. La recherche de l'identité. Positif. 542, April, 97-100.

9 Braham, Randolph, 1994. The Politics of Genocide: the Holocaust in Hungary. New York: Columbia University Press; Fejtö, François, 1997. Hongrois et juifs. Paris: Balland,

10 See Portuges, Catherine, 1995. Exile and return: Jewish Identity in Post-Communist Hungarian Cinema. Discourse: Journal for Theoretical Studies in Media and Culture, 17 (3), Spring, 24-37 and Portuges, Catherine, 2013. Memory and Reinvention in Post-Socialist Hungarian Cinema. In: Portuges, Catherine, Hames, Peter, eds. Cinema in Transition in Central and Eastern Europe after 1989. Philadelphia: Temple University Press, 104-131.

11 Sunshine was released in Canada in 1999 and in Europe in 2000, produced by a Canadian-Hungarian producer, Robert Lantos. The team is primarily Anglo-American and the film was shot in English in Hungary.

12 On the variations in the Hungarian historical narrative and its uses in cinema, see Gradvolh, Paul, Klimo, Arpad von, 2003. Représentations et usages de l'histoire. In: Théorème 7, Hungarian Cinema, Paris: PSN, 10-23. Also see Identité nationale et histoire en Hongrie, Historiens et Géographes, 366(1999).

13 See Loewy, Hanno, 2003. Contes tragiques, Heimatfilme ou mélodrames? Les générations allemandes et l'Holocauste. Questions de communication, 4, 343-364.

14 See Susan Suleiman's excellent article, Sunshine et les juifs de Hongrie. In: Théorème 7, Hungarian Cinema, PSN, Paris, 2003, 132-147; initially published under the title Suleiman, Susan, 2001. Jewish assimilation, the Holocaust and Epic Film: Reflections on István Szabó’s Sunshine. Yale Journal of Criticism, 14 (1), 233-252. 
15 Returning to this past allows for the reconstruction of this identity as evidenced by the Viennese sociologist Michael Pollak's L'Expérience concentrationnaire. Essai sur le maintien de l'identité sociale. Paris: Métailié, 1990 and Annette Wievorka's, L'ère du témoin. Paris: Plon, 1994.

16 As explained by Imre Kertész in an interview: “A book and film are two different things. In the novel, there is a different relationship to my own experience. In this way, while writing the novel, Fatelessness, I was very strict in terms of formal considerations, and I removed everything that was anecdotal. For the script, I was more flexible and I added some elements of my memories, moments that I lived and that I had not dared to put in the novel.” Interview with Michel Ciment, Positif. 542, April 2006, 88. Also see Bori, Erzsébet, 2005. The second wave: speaking out on the Holocaust. The Hungarian Quarterly, Spring, 177. Concerning it’s kitsch, Catherine Coquio La réception d'Etre sans destin, de Lajos Koltai : scandale et énigme, Revue d'histoire de la Shoah : Les écrans de la Shoah , 2011/2/n 195, pp 587-619.

17 A debate which raised a number of controversies outside of Hungary, e.g. Friedlander, Saul, ed. 1992. Probing the Limits of Representation: Nazism and the Final Solution. Cambridge: Harvard University Press; Elizer, Barbie, ed. 2001. Visual Culture and the Holocaust, London: Athlone Press; Hornstein, Shelly, Jacobowitz, Florence, eds. 2003. Image and Remembrance: Representation and the Holocaust. Bloomington: Indiana University Press; Saxton, Libby, 2008. Haunted images: Film, Ethics, Testimony and the Holocaust. London: Wallflower Press.

18 See Feigelson, Kristian, 2011. Cinematic archives and the rereading of European history in Forgács's cinema: A filmmaker of the anonymus. In: Hagin, Boaz, Meiri, Sandra, Yosef, Raz and Zanger, Anat eds. Just Images: Ethics and the Cinema, Newcastle: Cambridge Scholar Publishing, 142-157; Renov, Michael, 2011. Historical Discourses of the Unimaginable: The Maelstrom. In: Renov, Michael, Nichols, Bill, eds. Cinema's Alchemist: The Films of Peter Forgács. Minneapolis: University of Minnesota Press, 85- 95.

19 Portuges, Catherine, 2012. Jewish identities and generational perspectives in Hungarian cinema. In: Imre, Anikó, ed. A Companion to Eastern European Cinemas. London: Wiley-Blackwell, 101-124.

20 From Nemes's Q\&A following the U.S. premiere of Son of Saul, 53rd New York Film Festival, Walter Reade Theater, New York City, October 5, 2015, and from C. Portuges's personal interview with the film's editor, Mathieu Taponnier, Paris, November 5, 2015.

21 Television interview broadcast, Charlie Rose (WGBY-TV), January 4, 2016.

22 László Nemes, Golden Globes Foreign Film Nominee Directors Symposium, American Cinémathèque/Egyptian Theater, Hollywood, January 9, 2016.

23 Georges Didi-Huberman's controversial book, Images malgré tout. Paris: Les Editions de Minuit, 2004, prompted this comment from Nemes.

24 In 2001, an exhibition entitled Photographies des camps de concentration et d'extermination nazis (1993-1999) took place at the Hôtel de Sully; it was curated by Clément Chéroux.

25 Georges Didi-Huberman subsequently wrote a text as an open letter to Nemes published in a volume Sortir du noir. Paris: Les Editions de Minuit, 2015, just after the release of Son of Saul. 
26 With regard to the previously cited exhibition in 2001, Claude Lanzmann's reaction was as follows: "J'ai réalisé Shoah contre toute archive. J'ai vu pendant que je préparais Shoah, un film muet d'une minute, tourné par un soldat allemand qui montre des juifs exécutés par des Einzatsgruppen. Ce sont des images sans imagination...Le vrai problème dans cette histoire, est celui du statut de la photographie. Elle atteste quoi? La question n'est pas celle du document comme le pense Chéroux (commissaire de l'exposition), mais celle de la vérité ». in Le Monde, 19 janvier 2001. The four photographs of executions of Jewish deportees taken by the SS in Birkenau were shown again in the exhibition Soulèvements at the Musée du Jeu de Paume/Paris in 2016, entrusted to Georges Didi-Huberman. 
